Brief Report

\title{
Serum 'Vitamin-Mineral' Profiles: Associations with Postmenopausal Breast Cancer Risk Including Dietary Patterns and Supplementation. A Case-Control Study
}

\author{
Beata Krusinska $^{1, *}{ }^{\oplus}$, Lidia Wadolowska ${ }^{1} \oplus$, Maciej Biernacki ${ }^{2}$, Malgorzata Anna Slowinska ${ }^{1}$ \\ and Marek Drozdowski ${ }^{3}$ \\ 1 Department of Human Nutrition, University of Warmia and Mazury in Olsztyn, Sloneczna 45f, 10-718 \\ Olsztyn, Poland; lidia.wadolowska@uwm.edu.pl (L.W.); malgorzata.slowinska@uwm.edu.pl (M.A.S.) \\ 2 Department of Surgery, University of Warmia and Mazury in Olsztyn, 11-041 Olsztyn, Poland; \\ maciej.biernacki@uwm.edu.pl \\ 3 Department of Laboratory Medicine, University of Warmia and Mazury in Olsztyn, 11-041 Olsztyn, Poland; \\ marek.drozdowski@uwm.edu.pl \\ * Correspondence: beata.krusinska@uwm.edu.pl; Tel.: +48-895245518
}

Received: 15 August 2019; Accepted: 16 September 2019; Published: 18 September 2019

check for updates

\begin{abstract}
Breast cancer is the most prevalent cancer in females worldwide. Studies evaluating the blood vitamins and minerals status in the breast cancer etiology are limited, and the results are inconclusive. This study analyzed the association between serum vitamin-mineral profiles (V-MPs) and breast cancer (BC) risk with including dietary patterns (DPs) and the use of supplements. This case-control study involved 420 women aged 40-79 years from north-eastern Poland, including 190 newly diagnosed breast cancer cases. The fasting serum concentrations of vitamins (folate, cobalamin, $25(\mathrm{OH})$ vitamin $\mathrm{D})$ and minerals (iron, calcium, magnesium) were measured in 129 post-menopausal women, including 82 controls and 47 cases. Three V-MPs were derived with a Principal Component Analysis (PCA). A logistic regression analysis was performed to estimate the odds ratio (OR) and 95\% confidence interval ( $95 \% \mathrm{CI}$ ) of the breast cancer risk associated with serum V-MPs and serum levels of single biomarkers. The risk of BC was lower by $88 \%$ (OR: $0.12 ; 95 \% \mathrm{Cl}: 0.02-0.88 ; p<0.05)$ in the upper tertile of the serum 'Iron-Calcium' profile compared to the bottom tertile, lower by $67 \%$ (OR: $0.33 ; 95 \% \mathrm{Cl}: 0.11-0.97 ; p<0.05$ ) at the level of serum $25(\mathrm{OH})$ vitamin $\mathrm{D} \geq 24.6 \mathrm{ng} / \mathrm{mL}$ and lower by $68 \%$ (OR: $0.32 ; 95 \% \mathrm{Cl}: 0.11-0.91 ; p<0.05)$ at the level of serum calcium $\geq 9.6 \mathrm{mg} / \mathrm{dL}$. There was an inverse association of the serum 'Magnesium' profile or serum level of iron with the risk of BC, which disappeared after adjustment for the set of confounders accounted for: age, body mass index (BMI), socioeconomic status, overall physical activity, smoking status, age at menarche, number of full-term pregnancies, oral contraceptive use, hormone-replacement therapy use, family history of breast cancer, vitamin/mineral supplement use, the molecular subtype of breast cancer, and dietary patterns. No significant association was found between BC risk and the serum 'Folate-Cobalamin-Vitamin D' profile or serum folate, cobalamin or magnesium considered separately. These findings highlight that a higher-normal serum level of both iron and calcium, considered together as the serum profile, as well as a higher-normal serum level of calcium, considered separately, and a slightly below the normal range of serum vitamin $\mathrm{D}$ level may protect against breast cancer among postmenopausal women, independent of dietary patterns or the use of vitamin/mineral supplements. Therefore, the maintenance of the adequate status of vitamins and minerals and the regular monitoring of their blood markers should be included in breast cancer prevention.
\end{abstract}

Keywords: breast cancer; serum vitamin level; serum mineral level; dietary pattern; supplementation 


\section{Introduction}

Breast cancer is the most commonly diagnosed cancer and the leading cause of cancer deaths among women worldwide [1]. It is considered an important public health problem throughout the world, especially in economically developed and developing countries [1]. It accounts for approximately $24 \%$ of the total female cancer cases and $15 \%$ of the total female cancer deaths worldwide [2]. In Poland, breast cancer is the most commonly diagnosed cancer and is second only to lung cancer of cancer deaths in women [3]. Breast cancer accounts for approximately $22 \%$ and $14 \%$ of total female cancer cases and deaths in Polish females, respectively [1]. The risk of breast cancer increases with age. It is estimated that as many as $80 \%$ of breast cancer incidences occur in postmenopausal women, with nearly $50 \%$ of cases diagnosed between 50-69 years of age [3].

Besides age, the multifactorial etiology of breast cancer also includes: Genetic, reproductive, and lifestyle factors [4]. A direct cause of carcinogenesis are mutations in genes encoding proteins involved in the cell cycle [5]. Gene mutations and aberrant gene expression could result from epigenetic mechanisms, including aberrations of DNA (deoxyribonucleic acid) methylation, which can be modified by environmental factors such as diet [6]. The involvement of nutrients in cancer etiology include direct mechanisms through interactions with genes or indirect actions through an influence on DNA [6]. In the context of breast cancer risk, the current findings are mostly focused on single nutrient intake, with limited evidence of blood biomarker levels, which may better reflect nutrient status from various sources, including supplements and endogenous synthesis, not only dietary sources [4,7-10].

In regard to the water-soluble B-vitamins, folate, and vitamin B12 are important co-factors involved in one-carbon metabolism which plays a role in DNA synthesis, methylation, stability, and repair [8]. There are limited studies evaluating the association between serum folate or vitamin B12 and human breast cancer risk, and the results are mixed [11]. Some large prospective and case-control studies suggest an inverse association between folate and vitamin B12 status and breast cancer [11,12], while other cohort studies suggest that high levels of these vitamins may increase the risk of cancer [9,13-15]. This inconsistency among various studies may be related to differences in study design, sample sizes, statistical methods, the set of confounders taken into account, and the use of different cut-off points according to serum levels of these vitamins. Regarding fat-soluble vitamins, many beneficial roles in mammary cells, through immune-related functions and DNA methylation regulation, are played by vitamin D [16]. The anticarcinogenic properties of vitamin D were found in cellular in vitro models [17]. A protective effect of vitamin D against human breast cancer has been reported in most of the observational studies [18-29], although not all [30-32].

In regard to the minerals, calcium $(\mathrm{Ca})$, magnesium $(\mathrm{Mg})$, and iron $(\mathrm{Fe})$ also appear to be involved in breast cancer etiology [33,34]. Calcium is an important intracellular cation, which plays a role in cell signaling, regulating cell proliferation, differentiation, and apoptosis [33]. Decreased intracellular calcium level may stimulate the proliferation of cancer-transformed cells with simultaneous inhibition of cell differentiation and apoptosis, which promotes tumor growth [33]. There is limited data regarding the association between serum calcium levels and the risk of breast cancer among women and the findings are inconsistent [31,35-39]. This inconsistency could result from methodological differences between the studies, particularly the menopausal status of the enrolled sample, which associated calcium metabolism and breast density [36]. Magnesium is essential for DNA duplication and repair, and $\mathrm{Mg}$ deficiency promotes DNA mutations leading to carcinogenesis [38]. There is a lack of data on the serum magnesium level associated with the risk of breast cancer. Recently, it has been suggested that the ratio of serum calcium to magnesium may be linked with the risk of cancer [38]. Iron is an essential micronutrient which plays an important role in oxygen transport and DNA synthesis. On the other hand, iron catalyzes the production of reactive oxygen species, resulting in increased oxidative stress, mutations, DNA breaks, and oncogenic activation [39]. The carcinogenic potential of iron shown in the in vitro models [39] was supported by the results from observational studies related to iron status and postmenopausal breast cancer incidence [40-43]. However, there is limited data in this area. 
B-group vitamins, vitamin D, calcium, magnesium, and iron play a role at various stages of cancer development; from an impact on cellular genetic material and gene expression to a role in DNA synthesis, methylation, and stability, and an influence on cell proliferation, differentiation, and apoptosis $[6,17,33,38,39]$. The available studies have examined the association of single blood vitamin and mineral level with human breast cancer [12,14,18-29,32,33,35-37,39-42]. This approach does not include the interactions between the various biomarkers. The metabolism of nutrients is interrelated. An example would be the interaction of B-group vitamins, calcium, and vitamin D and calcium, magnesium, and iron [11,34,36,38]. Therefore, nutrient-nutrient interactions could impact cell metabolism and result in the weakening or strengthening of the risk of cancer [44]. Given the complex etiology of breast cancer, possible nutrient-nutrient interactions and the common mechanisms involving the mentioned nutrients in cancer etiology proven in vitro model studies, a comprehensive approach focused on both vitamins and mineral serum concentrations is needed to provide clear evidence of nutrient-breast cancer associations in observational human studies.

The aims of the study were: (1) to assess the breast cancer risk for a higher versus lower level of serum folate, vitamin B12, vitamin D, iron, calcium, and magnesium; and (2) to evaluate the joint association of these biomarkers as serum vitamin-mineral profiles (V-MPs) with the risk of breast cancer in postmenopausal women from north-eastern Poland. In these observations, many potential confounders, including dietary patterns were taken into account. Dietary patterns (DPs) express the complexity of the diet and are currently considered the best approach to evaluating the diet as a matrix of various foods and therefore the main source of nutrients status [4]. Thus, it was decided to take into account DPs identified based on previous data from the study regarding the association between DPs and breast cancer risk among peri and postmenopausal women from the same region [45]. Furthermore, the self-declared vitamin/mineral supplements use as the additional, next to diet, nutrients sources were also taken into account [10].

\section{Materials and Methods}

\subsection{Ethical Approval}

This study was approved by the Bioethics Committee of the Faculty of Medical Sciences, University of Warmia and Mazury in Olsztyn on 2 October 2013 (resolution no. 29/2013).

The aim of the study, study stages, and sample collection procedures were explained to all subjects. All subjects gave their written informed consent to participate in the study, including for blood sample collection and to use clinical data for research.

\subsection{Study Design}

The present study was a part of a larger case-control study conducted in 2014-2017, concerning dietary patterns and breast cancer risk among 420 women from north-eastern Poland [41]. Briefly, in this study, the cancer-control sub-sample involved 129 subjects, aged 45.0-79.9 (mean 61.9 SD 8.2) years, including 47 newly diagnosed breast cancer cases (cancer sub-sample) and 82 women without any breast pathology based on the mammography and/or breast ultrasonography screening (control sub-sample). All breast cancer cases were diagnosed by oncologists based on histopathology results from a biopsy at the Ministry of Internal Affairs Hospital with the Warmia and Mazury Oncology Centre in Olsztyn. The time from cancer diagnosis to case recruitment in the study ranged from seven to 28 days [45]. Cancer and control subjects were non-randomly recruited from January 2016 to June 2017. Details of the study design and sample collection were described previously [45]. In the cancer cases, the most frequency diagnosed were tumors with positive estrogen $(\mathrm{ER}+)$ and/or progesterone receptor status (PR+) and negative human epidermal growth factor receptor 2 (HER2-) of cancer (74\%; Luminal A; Figure 1), which are the most common molecular subtype of breast cancers worldwide, including Poland [1]. The inclusion and exclusion criteria of the cancer and control sub-samples 
collection are shown in Table 1. All data were collected before treatment or surgical intervention in cancer cases to avoid reverse causation.

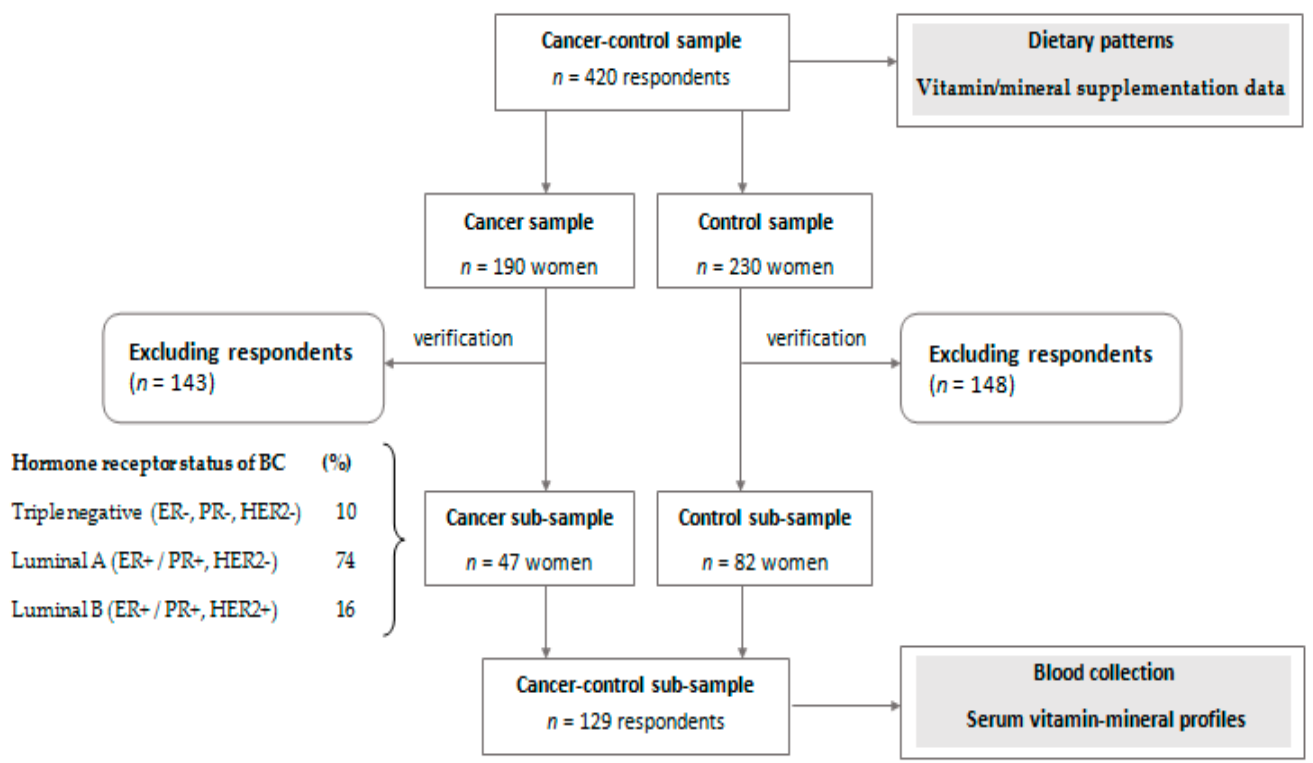

Figure 1. Study design and sample collection. BC—breast cancer; ER-estrogen receptor status of tumor; PR—progesterone receptor status of tumor; HER2—human epidermal growth factor receptor 2.

Table 1. Criteria of the cancer and control sub-sample collection.

\begin{tabular}{cc}
\hline Inclusion Criteria & Exclusion Criteria \\
\hline women & diabetes \\
north-eastern Poland (urban and rural areas) & atherosclerosis \\
post-menopausal status (natural menopause) & infections \\
mammography and/or ultrasonography of breasts & autoimmune diseases \\
without chronic diseases or infections & hormonal disorders \\
fasting status at time of blood sampling & hysterectomy \\
consent to blood collection & non-fasting status \\
\hline
\end{tabular}

\subsection{Blood Samples and Laboratory Analyses}

Fasting venous blood samples were collected for 129 postmenopausal women, including 47 preoperative breast cancer cases and 82 controls. The procedure of the blood sample collection and the serum obtaining were described previously [45]. In brief, a $12 \mathrm{~mL}$ blood samples were taken in two $6 \mathrm{~mL}$ red top tubes (Clot Activator Tube; BD Vacutainer ${ }^{\circledR}$, Franklin Lakes, NJ, USA). Blood samples stood for $30 \mathrm{~min}$ at $22{ }^{\circ} \mathrm{C}$, and then were centrifuged at $3000 \mathrm{rpm}$ for $10 \mathrm{~min}$ at $22{ }^{\circ} \mathrm{C}$, which allowed the separated serum obtained. The case-control status of the blood samples was blinded. All methods were fully automated and performed at the Laboratory of Biochemical Studies of Nutritional Status in the Department of Human Nutrition at the University of Warmia and Mazury in Olsztyn.

Iron, calcium, and magnesium concentrations were measured in serum samples using a Cobas Integra 400 plus auto-analyzer (Roche Diagnostics ${ }^{\circledR}$, Basel, Switzerland) according to the manufacturer's instructions. Serum concentrations of folate, cobalamin, and $25(\mathrm{OH})$ vitamin D were measured with electrochemiluminescence immunoassays (ECLIA) using an automated immune-analyzer Cobas e411 (Roche Diagnostics ${ }^{\circledR}$, Basel, Switzerland). The minimum detectable concentrations (MDC) were as follows: iron $5.00 \mu \mathrm{g} / \mathrm{dL}$, calcium $0.8 \mathrm{mg} / \mathrm{dL}$, magnesium $0.36 \mathrm{mg} / \mathrm{dL}$, folate $0.640 \mathrm{ng} / \mathrm{mL}$, cobalamin $100 \mathrm{pg} / \mathrm{mL}$, and $25(\mathrm{OH})$ vitamin D $3.00 \mathrm{ng} / \mathrm{mL}$. 


\subsection{Identification of Serum Vitamin-Mineral Profiles}

The Principal Component Analysis (PCA) with varimax rotation was used to identify (a posteriori approach) serum vitamin-mineral profiles (V-MPs). The values of serum vitamins and mineral concentrations were standardized and then included into the PCA. During identification of the number of serum V-MPs, the following criteria were considered: (i) the eigenvalues of the variable correlations $>1.0$, (ii) the plot of eigenvalues, and (iii) the total variance explained [46]. Serum V-MPs were identified according to their main components with absolute factor loadings $>|0.50|$, which indicated a strong association between biomarker and the serum V-MP.

Three serum V-MPs were identified (Table 2). The 'Folate-Cobalamin-Vitamin D' profile was positively loaded by the serum concentration of folate, cobalamin and $25(\mathrm{OH})$ vitamin $\mathrm{D}$. The 'Iron-Calcium' profile was positively loaded by the serum concentration of iron and calcium. The 'Magnesium' profile was positively loaded by the serum concentration of magnesium (Table 2). For each of the serum V-MPs, tertile intervals, as well as, the V-MP scores (in points) as a sum of the product of the biomarkers values and its factor loadings were calculated.

Table 2. Factor loadings for serum vitamins and mineral concentrations in Principal Component Analysis (PCA)-derived profiles among postmenopausal women $(n=129)$.

\begin{tabular}{cccc}
\hline \multirow{2}{*}{ Biomarkers } & \multicolumn{3}{c}{ Vitamin-Mineral Profiles } \\
\cline { 2 - 4 } & 'Folate-Cobalamin-Vitamin D' & 'Iron-Calcium' & 'Magnesium' \\
\hline Folate & $\mathbf{0 . 8 2}$ & -0.06 & -0.07 \\
Cobalamin & $\mathbf{0 . 8 1}$ & 0.12 & 0.04 \\
25(OH) vitamin D & $\mathbf{0 . 4 9}$ & 0.05 & 0.39 \\
Iron & 0.09 & $\mathbf{0 . 8 1}$ & -0.17 \\
Calcium & -0.02 & $\mathbf{0 . 7 7}$ & 0.22 \\
Magnesium & 0.00 & 0.01 & $\mathbf{0 . 9 2}$ \\
\hline Share in explaining the & 28 & 20 & 17 \\
$\quad$ variance (\%) & \multicolumn{2}{c}{} \\
\hline Bolded values are marked for the main components of serum PCA-derived profiles with absolute factor loadings \\
$\geq 0.5$.
\end{tabular}

\subsection{Dietary Assessment}

Dietary data were collected for 420 peri and postmenopausal women, including 190 breast cancer cases and 230 controls [45]. The frequency consumption of 62 food groups at least 12 months prior to participation in the study was obtained using a validated the 62-item Food Frequency Questionnaire (FFQ-6) $[47,48]$. The frequency consumption of some food groups (expressed as times/day) was summed up to form 21 food groups (Table S1), and then was standardized and input into the PCA with varimax rotation to identify dietary patterns (Table 3). The criterions of the PCA-derived DPs identification were described previously [45]. For each of the DPs, the DPs scores (in points) as a sum of the product of the frequency of food consumption and its factor loadings were calculated.

\subsection{Confounders}

Data regarding socioeconomic, lifestyle, reproductive, and medical factors were collected in an individual interview with each participant. The set of confounders included the factors given below, which can be involved in the breast cancer etiology [4]:

- age;

- body mass index;

- $\quad$ socioeconomic status;

- overall physical activity;

- smoking status; 
- $\quad$ age at menarche;

- number of full-term pregnancies;

- oral contraceptive use;

- hormone-replacement therapy use;

- family history of breast cancer;

- vitamin/mineral supplement use;

- molecular subtype of breast cancer;

- $\quad$ PCA-derived dietary patterns (in scores).

Table 3. Description of PCA-derived dietary patterns (DPs) among peri and postmenopausal women $(n=420)$.

\begin{tabular}{|c|c|}
\hline Dietary Patterns & Components ${ }^{1}$ of DPs (Factor Loadings ${ }^{2}$ ) Related to Food Consumption Frequency ${ }^{3}$ of: \\
\hline 'Non-Healthy' & $\begin{array}{c}\text { refined cereals and fine groats }(0.67) \text {, red and processed meats }(0.63) \text {, sugar, honey and } \\
\text { sweets }(0.57) \text {, potatoes }(0.55) \text {, animal fats }(0.49) \text {, vegetable based oil }(0.34) \text {, sweetened } \\
\text { beverages and energy drinks }(0.32) \text {, wholemeal cereals and coarse groats }(-0.45) \text {, nuts and } \\
\text { seeds }(-0.39) ;\end{array}$ \\
\hline ‘Prudent' & $\begin{array}{c}\text { fruits }(0.55) \text {, fish }(0.49) \text {, legumes }(0.48) \text {, milk and milk beverages-natural and cheese curds } \\
(0.48) \text {, wholemeal cereals and coarse groats }(0.47) \text {, fruit, vegetable or vegetable-fruit juices } \\
(0.45) \text {, eggs and egg dishes }(0.44) \text {, vegetables }(0.42) \text {, nuts and seeds }(0.42) \text {, vegetable based } \\
\text { oil }(0.36) \text {, breakfast cereals }(0.35) \text {, cheese }(0.34) \text {; }\end{array}$ \\
\hline 'Margarine and Sweetened Dairy' & $\begin{array}{l}\text { other fats: margarine, mayonnaise and dressings }(0.80) \text {, milk beverages-sweetened and } \\
\text { flavoured cheese curds }(0.36) \text {, white meat }(0.31) \text {, breakfast cereals }(0.31) \text {, animal fats }(-0.66) \text {. }\end{array}$ \\
\hline \multicolumn{2}{|c|}{$\begin{array}{l}1 \text { description of the full list of food groups was shown in Supplementary Materials (Table S1) [48]; }{ }^{2} \text { values for the } \\
\text { main components of PCA-derived dietary patterns with absolute loadings } \geq 0.3 \text {; and }{ }^{3} \text { the frequency consumption } \\
\text { was expressed as times/day after assigning the appropriate values as follows: 'never or almost never' }=0 \text {; 'once a } \\
\text { month or less' }=0.025 \text {; 'several times a month' }=0.1 \text {; 'several times a week' }=0.571 \text {; 'daily' }=1 \text {; 'several times a day' } \\
=2[48] .\end{array}$} \\
\hline
\end{tabular}

Respondents were asked about four single factors to describe their socioeconomic status (SES). The SES index was calculated as the sum of the values assigned to the response categories of each SES factor (Table 4). The SES index values were logarithmized and the tertiles of the SES were then created to identify respondents with low, average, and high SES.

Table 4. Description of the socioeconomic status factors [45].

\begin{tabular}{|c|c|c|}
\hline Socioeconomic Factors & Categories & Scoring \\
\hline \multirow{4}{*}{ place of residence } & village & 1 \\
\hline & town $<20,000$ & 2 \\
\hline & town $20,000-100,000$ inhabitants & 3 \\
\hline & city $>100,000$ inhabitants & 4 \\
\hline \multirow[b]{2}{*}{ educational level } & primary & 1 \\
\hline & secondary & 2 \\
\hline \multirow{2}{*}{$\begin{array}{l}\text { economic situation } \\
\text { (self-declared) }\end{array}$} & average & 2 \\
\hline & above average & 3 \\
\hline \multirow[b]{2}{*}{$\begin{array}{l}\text { situation of household } \\
\quad \text { (self-declared) }\end{array}$} & $\begin{array}{l}\text { we live poorly-I don't have enough resources even for basic needs } \\
\text { (food/clothing/housing fees) }\end{array}$ & 1 \\
\hline & $\begin{array}{l}\text { we live very thriftily - I have enough resources only for basic needs } \\
\text { (food/clothing/housing fees) }\end{array}$ & 2 \\
\hline
\end{tabular}

Scoring-values assigned to the response categories.

Respondents were asked to describe their physical activity at work and physical activity in leisure time by choosing one of three categories (Table 5). Self-declared data was then combined, and three categories of overall physical activity were created: low, moderate, and high (Table 6). 
Table 5. Description of the categories of physical activity at work and at leisure time [45].

\begin{tabular}{|c|c|c|}
\hline $\begin{array}{l}\text { Physical } \\
\text { Activity }\end{array}$ & Categories & Description \\
\hline \multirow{3}{*}{ at work } & low & more than $70 \%$ of working time spent sedentary or retired \\
\hline & moderate & $\begin{array}{l}50 \% \text { of working time spent sedentary and } 50 \% \text { of working time spent in } \\
\text { an active manner }\end{array}$ \\
\hline & high & $\begin{array}{l}70 \% \text { of working time spent in an active manner or physical work related } \\
\text { to great exertion }\end{array}$ \\
\hline \multirow{3}{*}{ at leisure time } & low & $\begin{array}{l}\text { sedentary for most of the time, watching TV, reading books, walking } \\
\qquad 1-2 \mathrm{~h} / \text { week }\end{array}$ \\
\hline & moderate & $\begin{array}{l}\text { walking, bike riding, gymnastics, gardening, light physical activity } \\
\text { performed } 2-3 \mathrm{~h} / \text { week }\end{array}$ \\
\hline & high & $\begin{array}{l}\text { bike riding, jogging, gardening, sport activities involving physical } \\
\text { exertion performed more than } 3 \mathrm{~h} \text { weekly }\end{array}$ \\
\hline
\end{tabular}

Table 6. Estimate the overall physical activity after combining data based on self-reported physical activity at work and physical activity in leisure time [49].

\begin{tabular}{|c|c|c|c|c|}
\hline & & \multicolumn{3}{|c|}{ Physical Activity at Work } \\
\hline & & Low & Moderate & High \\
\hline $\begin{array}{l}\text { Physical activity in } \\
\text { leisure time }\end{array}$ & $\begin{array}{c}\text { low } \\
\text { moderate } \\
\text { high }\end{array}$ & $\begin{array}{c}\text { low } \\
\text { low } \\
\text { moderate }\end{array}$ & $\begin{array}{l}\text { low } \\
\text { moderate } \\
\text { moderate }\end{array}$ & $\begin{array}{c}\text { moderate } \\
\text { moderate } \\
\text { high }\end{array}$ \\
\hline
\end{tabular}

\subsection{Statistical Analysis}

The serum biomarker concentrations were expressed by the mean and standard deviation (SD). The continuous log values of biomarkers and Student's t-test were used to compare them between cases and controls. The median (Me) of the biomarker concentrations was used to divide subjects into two categories $(<\mathrm{Me}, \geq \mathrm{Me})$. The categorical variables were presented in percentages. Differences in baseline case-control characteristics were verified with a Pearson $\mathrm{Chi}^{2}$ test (categorical data) or a Kruskal-Wallis test (continuous data) [46]. The percentage distribution of breast cancer cases was compared by tertiles of serum V-MPs using Pearson $\mathrm{Chi}^{2}$ test with Yates' correction as necessary. Logistic regression analysis was used to estimate the odds ratio (OR) and $95 \%$ confidence interval (95\% $\mathrm{CI}$ ) of the breast cancer risk in associations with serum V-MPs and serum levels of single biomarkers. The references $(\mathrm{OR}=1.00)$ were the control sample and the bottom tertile of each serum V-MPs or lower level of single biomarker concentration $(<\mathrm{Me})$. Three models were created: model 1 -unadjusted, model 2-adjusted for the aforementioned set of confounders, and model 3-fully-adjusted for the same confounders included in the model 2 and for DP scores. The level of significance of the OR was verified with Wald's test [46]. $p$ values $<0.05$ were considered as statistically significant. All data were analyzed using STATISTICA software (version 13.0 PL; StatSoft Inc., Tulsa, OK, USA; StatSoft, Krakow, Poland).

\section{Results}

\subsection{Baseline Sample Characteristics}

The baseline characteristics of the cancer-control sub-sample are shown in Table 7. All women were postmenopausal. Cancer cases and controls did not differ in age or BMI. Compared to the controls, more breast cancer cases occurred among women with lower socioeconomic status, more were less physically active or had at least three full-term pregnancies. Breast cancer cases had, on average, a higher score of the 'Non-healthy' dietary pattern than controls. About half of the participants self-declared use of vitamin and/or mineral supplements within the last 12 months. None of the participants abused alcohol (Table 7). The comparative characteristics of cancer and control samples with their sub-samples are shown in Supplementary Tables S2-S4. 
Table 7. Cancer-control sub-sample characteristics (\% or points).

\begin{tabular}{|c|c|c|c|c|}
\hline Variable & $\begin{array}{l}\text { Cancer-Control } \\
\text { Sub-Sample }\end{array}$ & $\begin{array}{c}\text { Cancer } \\
\text { Sub-Sample }\end{array}$ & $\begin{array}{c}\text { Control } \\
\text { Sub-Sample }\end{array}$ & $p$-Value \\
\hline Sample Size & 129 & 47 & 82 & \\
\hline Age (years \#) & $61.9(8.2)$ & $62.2(10.4)$ & $61.7(6.7)$ & 0.5724 \\
\hline BMI $\left(\mathrm{kg} / \mathrm{m}^{2 \#}\right)$ & $27.9(5.1)$ & $28.8(5.1)$ & $27.3(5.1)$ & 0.0743 \\
\hline Socioeconomic status (SES Index ${ }^{\#}$ ) & $9.9(2.3)$ & $8.4(1.8)$ & $10.8(2.1)$ & 0.0001 \\
\hline low & 40.8 & 69.4 & 23.5 & \\
\hline average & 35.4 & 28.6 & 39.5 & 0.0001 \\
\hline high & 23.8 & 2.0 & 37.0 & \\
\hline \multicolumn{5}{|l|}{ Overall physical activity ${ }^{1}$} \\
\hline low & 56.2 & 71.4 & 46.9 & \multirow{3}{*}{0.0229} \\
\hline moderate & 41.5 & 26.5 & 50.6 & \\
\hline high & 2.3 & 2.0 & 2.5 & \\
\hline Sample Size & 129 & 47 & 82 & \\
\hline Smoking status (smoker ${ }^{2}$ ) & 46.2 & 55.1 & 40.7 & 0.1114 \\
\hline Abuse of alcohol ${ }^{3}$ & 0.0 & 0.0 & 0.0 & 1.0000 \\
\hline \multicolumn{5}{|l|}{ Age at menarche (years) } \\
\hline$<12$ & 7.7 & 14.3 & 3.7 & \multirow{3}{*}{0.0792} \\
\hline $12-14.9$ & 70.0 & 67.4 & 71.6 & \\
\hline$\geq 15$ & 22.3 & 18.4 & 24.7 & \\
\hline \multicolumn{5}{|l|}{ Menopausal status } \\
\hline pre-menopausal & 0.0 & 0.0 & 0.0 & \multirow[t]{2}{*}{1.0000} \\
\hline post-menopausal & 100.0 & 100.0 & 100.0 & \\
\hline \multicolumn{5}{|l|}{ Number of full-term pregnancies } \\
\hline 0 & 10.8 & 4.1 & 14.8 & \multirow{3}{*}{0.0084} \\
\hline $1-2$ & 62.3 & 55.1 & 66.7 & \\
\hline$\geq 3$ & 26.9 & 40.8 & 18.5 & \\
\hline Oral contraceptive use (ever) & 23.8 & 18.4 & 27.2 & 0.2542 \\
\hline $\begin{array}{l}\text { Hormone-replacement therapy use } \\
\text { (ever) }\end{array}$ & 22.3 & 20.4 & 23.5 & 0.6858 \\
\hline Family history of BC ${ }^{4}$ & 23.8 & 32.7 & 18.5 & 0.1278 \\
\hline Vitamin/mineral supplements use ${ }^{5}$ & 53.8 & 42.9 & 60.5 & 0.0506 \\
\hline \multicolumn{5}{|l|}{ Dietary patterns score ${ }^{\#}$ (points) } \\
\hline 'Non-Healthy' & $2.9(1.7)$ & $3.6(1.7)$ & $2.5(1.5)$ & 0.0003 \\
\hline 'Prudent' & $3.4(1.3)$ & $3.1(1.5)$ & $3.5(1.1)$ & 0.0607 \\
\hline 'Margarine and Sweetened Dairy' & $-0.1(0.9)$ & $0.1(1.0)$ & $-0.3(0.8)$ & 0.0999 \\
\hline
\end{tabular}

BMI-body mass index; BC—breast cancer; SES-socioeconomic status calculated on the basis of place of residence, education level, self-declared economic situation and self-declared household economic status situation (description in the Section 2.6.); ${ }^{1}$ calculated after combining data based on self-declared physical activity at work and physical activity in leisure time (description in the Section 2.6.) [49]; ${ }^{2}$ ever-smoker (current and/or former smoker); ${ }^{3}$ at least one bottle $(0.5 \mathrm{~L})$ of beer or two glasses of wine $(300 \mathrm{~mL})$, or two drinks $(300 \mathrm{~mL})$, or two glasses of vodka $(60 \mathrm{~mL})$ per day [50]; ${ }^{4}$ in first- or second-degree relative; and ${ }^{5}$ self-declared use of vitamin and/or mineral supplements within the last 12 months; \%-sample percentage; ${ }^{\#}$ mean and standard deviation (SD); $p$-value-level of significance verified with $\mathrm{chi}^{2}$ test (categorical variables) or Kruskal-Wallis' test (continuous variables).

\subsection{Vitamin-Mineral Profiles and Breast Cancer Risk}

Breast cancer cases had a lower mean score of the 'Folate-Cobalamin-Vitamin D' profile (300.8 versus 349.3 points), and the 'Iron-Calcium' profile (127.0 versus 142.7 points) than controls. Compared to the controls, the number of breast cancer cases was lower in the upper tertile of the 'Iron-Calcium' profile (24.5 versus 39.5\%), and the 'Magnesium' profile (18.4 versus $43.2 \%$ ) than the bottom tertile (Table 8).

Compared to the controls, breast cancer cases had a lower mean serum concentration of most of the selected vitamins and minerals: $25(\mathrm{OH})$ vitamin $\mathrm{D}(21.9$ versus $29.5 \mathrm{ng} / \mathrm{mL}$ ), iron ( 97.8 versus $108.3 \mu \mathrm{g} / \mathrm{dL}$ ), calcium (9.5 versus $9.6 \mathrm{mg} / \mathrm{dL}$ ), and magnesium (2.0 versus $2.1 \mathrm{mg} / \mathrm{dL}$ ), excluding folate and cobalamin. Compared to the controls, fewer cases of breast cancer had elevated levels of serum concentration of $25(\mathrm{OH}$ ) vitamin $\mathrm{D} \geq 24.6 \mathrm{ng} / \mathrm{mL}$ ( 34.0 versus $60.5 \%$ ), iron $\geq 103.0 \mu \mathrm{g} / \mathrm{dL}$ (38.0 versus 
$58.0 \%$ ), and calcium $\geq 9.6 \mathrm{mg} / \mathrm{dL}$ (46.0 versus $69.1 \%$; Table 8 ). On the other hand, more cancer cases had elevated levels of serum folate concentration $\geq 10.5 \mathrm{ng} / \mathrm{mL}$ ( 61.2 versus $43.2 \%$ ) than the controls. The mean ratio of serum calcium to magnesium was 4.6 for the total sample and was not significantly different between cases and controls (Table 8 ). The histograms of serum $25(\mathrm{OH})$ vitamin $\mathrm{D}$ and calcium concentrations among cancer and control sub-samples are shown in Figure S1. The sub-sample characteristics and serum concentration of vitamins and minerals by tertiles of serum V-MPs are shown in Supplementary Tables S5 and S6, respectively.

Table 8. Serum vitamin-mineral profiles and their components in association with breast cancer $(\%$ or points).

\begin{tabular}{|c|c|c|c|c|}
\hline Variable & $\begin{array}{c}\text { Cancer-Control } \\
\text { Sub-Sample }\end{array}$ & $\begin{array}{c}\text { Cancer } \\
\text { Sub-Sample }\end{array}$ & $\begin{array}{c}\text { Control } \\
\text { Sub-Sample }\end{array}$ & $p$-Value \\
\hline Sample Size & 129 & 47 & 82 & \\
\hline \multicolumn{5}{|l|}{ 'Folate-Cobalamin-Vitamin D' profile } \\
\hline Score $^{\#}$ (points) & $331.0(135.3)$ & $300.8(119.5)$ & $349.3(141.6)$ & 0.0424 \\
\hline \multicolumn{5}{|l|}{ tertiles } \\
\hline bottom & 33.1 & 40.8 & 28.4 & \multirow{3}{*}{0.3304} \\
\hline middle & 33.8 & 28.6 & 37.0 & \\
\hline upper & 33.1 & 30.6 & 34.6 & \\
\hline \multicolumn{5}{|l|}{ 'Iron-Calcium' profile } \\
\hline Score ${ }^{\#}$ (points) & $136.8(33.0)$ & $127.0(34.7)$ & $142.7(30.6)$ & 0.0045 \\
\hline \multicolumn{5}{|l|}{ tertiles } \\
\hline bottom & 33.8 & 46.9 & 25.9 & \multirow{3}{*}{0.0417} \\
\hline middle & 32.3 & 28.6 & 34.6 & \\
\hline upper & 33.8 & 24.5 & 39.5 & \\
\hline \multicolumn{5}{|l|}{ 'Magnesium' profile } \\
\hline Score ${ }^{\#}$ (points) & $10.6(9.8)$ & $8.4(8.1)$ & $12.0(10.5)$ & 0.0543 \\
\hline \multicolumn{5}{|l|}{ tertiles } \\
\hline bottom & 33.8 & 46.9 & 25.9 & \multirow{3}{*}{0.0079} \\
\hline middle & 32.3 & 34.7 & 30.9 & \\
\hline upper & 33.8 & 18.4 & 43.2 & \\
\hline Folate $(\mathrm{ng} / \mathrm{mL})$ \# & $11.8(7.4)$ & $12.4(6.5)$ & $11.5(7.9)$ & 0.4840 \\
\hline$\geq 10.5$ & 50.0 & 61.2 & 43.2 & 0.0465 \\
\hline Cobalamin $(\mathrm{pg} / \mathrm{mL})^{\#}$ & $369.2(160.9)$ & $334.9(144.4)$ & $389.9(167.5)$ & 0.0585 \\
\hline$\geq 341.65$ & 50.0 & 40.8 & 55.6 & 0.1034 \\
\hline $25(\mathrm{OH})$ vitamin $\mathrm{D}(\mathrm{ng} / \mathrm{mL})^{\#}$ & $26.6(13.7)$ & $21.9(10.2)$ & $29.5(14.7)$ & 0.0019 \\
\hline$\geq 24.6$ & 50.4 & 34.0 & 60.5 & 0.0032 \\
\hline Iron $(\mu \mathrm{g} / \mathrm{dL}) \#$ & $104.3(29.8)$ & $97.8(31.6)$ & $108.3(28.1)$ & 0.0429 \\
\hline$\geq 103.0$ & 50.4 & 38.0 & 58.0 & 0.0260 \\
\hline Calcium $(\mathrm{mg} / \mathrm{dL})^{\#}$ & $9.6(0.5)$ & $9.5(0.5)$ & $9.6(0.4)$ & 0.0290 \\
\hline$\geq 9.6$ & 60.3 & 46.0 & 69.1 & 0.0086 \\
\hline Magnesium (mg/dL) $\#$ & $2.1(0.1)$ & $2.0(0.1)$ & $2.1(0.1)$ & 0.0009 \\
\hline$\geq 2.1$ & 63.4 & 56.0 & 67.9 & 0.1696 \\
\hline Ratio of serum calcium to magnesium \# & $4.6(0.4)$ & $4.7(0.5)$ & $4.6(0.3)$ & 0.1222 \\
\hline
\end{tabular}

$\%$-sample percentage; ${ }^{\#}$ mean and standard deviation (SD); $p$-value-level of significance assessed by chi ${ }^{2}$ test (categorical variables) or Kruskal-Wallis' test (continuous variables) or Student's $t$-test (for log-transformed serum biomarkers concentration); $p<0.05 ; \mathrm{ns}$-statistically insignificant.

In the upper tertile of the serum 'Iron-Calcium' profile, the risk of breast cancer was lower by 66\% (OR: 0.34; 95\% Cl: 0.14-0.84; $p<0.05$; unadjusted model 1; reference: bottom tertile) and 88\% (OR: $0.12 ; 95 \%$ Cl: 0.02-0.88; $p<0.05$; fully-adjusted model 3; reference: bottom tertile; Table 9). In the upper tertile of the serum 'Magnesium' profile, the risk of breast cancer was lower by 77\% (OR: 0.23; 95\% Cl: $0.09-0.61 ; p<0.01$; unadjusted model 1; reference: bottom tertile) and 79\% (OR: $0.21 ; 95 \% \mathrm{Cl}$ : $0.05-0.84 ; p<0.05$; adjusted model 2; reference: bottom tertile). This association disappeared after the adjustment for dietary patterns (fully-adjusted model 3). The serum 'Folate-Cobalamin-Vitamin D' profile was not significantly associated with the risk of breast cancer (Table 9). 
Table 9. Odds ratios (ORs) and 95\% confidence interval (95\% CI) of breast cancer by adherence to the serum vitamin-mineral profiles and single biomarkers $(n=129)$.

\begin{tabular}{|c|c|c|c|c|c|c|c|c|c|}
\hline \multirow{3}{*}{$\begin{array}{l}\text { Serum 'Vitamin-Mineral' } \\
\text { Profiles/Single Biomarkers }\end{array}$} & \multirow{3}{*}{ Tertiles/Levels } & \multirow{3}{*}{ Sample Size } & \multicolumn{7}{|c|}{ Breast Cancer } \\
\hline & & & \multirow{2}{*}{ Percentage (\%) } & \multicolumn{2}{|c|}{ Unadjusted Model 1} & \multicolumn{2}{|c|}{ Model 2} & \multicolumn{2}{|c|}{ Model 3} \\
\hline & & & & ORs & $95 \% \mathrm{CI}$ & ORs & $95 \% \mathrm{CI}$ & ORs & $95 \% \mathrm{CI}$ \\
\hline \multirow{3}{*}{ 'Folate-Cobalamin-Vitamin D' } & bottom (ref.) & 43 & 40 & 1.00 (ref.) & & 1.00 (ref.) & & 1.00 (ref.) & \\
\hline & middle & 43 & 29 & 0.54 & $0.22 ; 1.30$ & 0.64 & $0.19 ; 2.15$ & 0.67 & $0.18 ; 2.45$ \\
\hline & upper & 43 & 31 & 0.62 & $0.26 ; 1.49$ & 1.27 & $0.47 ; 3.42$ & 1.30 & $0.46 ; 3.66$ \\
\hline \multirow{3}{*}{ 'Iron-Calcium' } & bottom (ref.) & 43 & 46 & 1.00 (ref.) & & 1.00 (ref.) & & 1.00 (ref.) & \\
\hline & middle & 42 & 29 & 0.46 & $0.19 ; 1.11$ & $0.26 *$ & $0.07 ; 0.94$ & 0.31 & $0.08 ; 1.21$ \\
\hline & upper & 44 & 25 & $0.34 *$ & $0.14 ; 0.84$ & $0.24 *$ & $0.06 ; 0.99$ & $0.12 *$ & $0.02 ; 0.88$ \\
\hline \multirow{3}{*}{ 'Magnesium' } & bottom (ref.) & 43 & 47 & 1.00 (ref.) & & 1.00 (ref.) & & 1.00 (ref.) & \\
\hline & middle & 42 & 35 & 0.62 & $0.26 ; 1.48$ & 0.56 & $0.16 ; 1.90$ & 0.73 & $0.20 ; 2.68$ \\
\hline & upper & 44 & 18 & $0.23 * *$ & $0.09 ; 0.61$ & $0.21 *$ & $0.05 ; 0.84$ & 0.26 & $0.05 ; 1.25$ \\
\hline \multirow{2}{*}{ Folate $(\mathrm{ng} / \mathrm{mL})$} & $<10.5$ (ref.) & 64 & 39 & 1.00 (ref.) & & 1.00 (ref.) & & 1.00 (ref.) & \\
\hline & $\geq 10.5$ & 65 & 61 & 2.07 & $0.97 ; 4.31$ & 2.02 & $0.91 ; 4.23$ & 2.01 & $0.90 ; 4.27$ \\
\hline \multirow{2}{*}{ Cobalamin (pg/mL) } & $<341.65$ (ref.) & 64 & 59 & 1.00 (ref.) & & 1.00 (ref.) & & 1.00 (ref.) & \\
\hline & $\geq 341.65$ & 65 & 41 & 0.55 & $0.27 ; 1.14$ & 0.72 & $0.29 ; 1.83$ & 0.66 & $0.24 ; 1.79$ \\
\hline \multirow{2}{*}{$25(\mathrm{OH})$ vitamin $\mathrm{D}(\mathrm{ng} / \mathrm{mL})$} & $<24.6$ (ref.) & 64 & 66 & 1.00 (ref.) & & 1.00 (ref.) & & 1.00 (ref.) & \\
\hline & $\geq 24.6$ & 65 & 34 & $0.34^{* *}$ & $0.16 ; 0.71$ & $0.28 *$ & $0.10 ; 0.78$ & $0.33 *$ & $0.11 ; 0.97$ \\
\hline \multirow{2}{*}{ Iron $(\mu \mathrm{g} / \mathrm{dL})$} & $<103.0$ (ref.) & 64 & 62 & 1.00 (ref.) & & 1.00 (ref.) & & 1.00 (ref.) & \\
\hline & $\geq 103.0$ & 65 & 38 & $0.44 *$ & $0.21 ; 0.92$ & 0.72 & $0.28 ; 1.82$ & 0.68 & $0.24 ; 1.92$ \\
\hline \multirow{2}{*}{ Calcium (mg/dL) } & $<9.6$ (ref.) & 51 & 54 & 1.00 (ref.) & & 1.00 (ref.) & & 1.00 (ref.) & \\
\hline & $\geq 9.6$ & 78 & 46 & $0.38^{* *}$ & $0.18 ; 0.79$ & $0.33 *$ & $0.12 ; 0.87$ & $0.32 *$ & $0.11 ; 0.91$ \\
\hline \multirow{2}{*}{ Magnesium (mg/dL) } & $<2.1$ (ref.) & 47 & 44 & 1.00 (ref.) & & 1.00 (ref.) & & 1.00 (ref.) & \\
\hline & $\geq 2.1$ & 82 & 56 & 0.60 & $0.29 ; 1.25$ & 0.54 & $0.21 ; 1.38$ & 0.63 & $0.23 ; 1.72$ \\
\hline $\begin{array}{l}\text { ref.-referent, the reference cate } \\
2-\text { age (years), BMI }\left(\mathrm{kg} / \mathrm{m}^{2}\right), \text { soc } \\
12-14.9, \geq 15 \text { years), number of fu } \\
\text { second-degree relative (no, I don' } \\
\text { luminal B) adjusted model; Mode } \\
p \text {-value - the level of sionificance }\end{array}$ & $\begin{array}{l}\text { ies were the con } \\
\text { conomic status ( } \\
\text { erm pregnancies }\end{array}$ & $\begin{array}{l}\text { rol sample and } \\
\text { ow, average, hi }\end{array}$ & $\begin{array}{l}\text { e bottom tertile } \\
\text { overall physica } \\
\text { ntraceptive use } \\
\text { ents use (no, yes }\end{array}$ & $\begin{array}{l}\text { erum 'Vita } \\
\text { tivity (low, } \\
\text { yes), horm } \\
\text { molecular } \\
\text { nodel } 2 \text { plu }\end{array}$ & $\begin{array}{l}\text {-Mineral' p } \\
\text { derate, high } \\
\text { replacemen } \\
\text { reast cance } \\
\text { A-driven D }\end{array}$ & $\begin{array}{l}\text { es or lowe } \\
\text { noking sta } \\
\text { rapy use } \\
\text { types (tri }\end{array}$ & $\begin{array}{l}\text { el of each } \\
\text { on-smoke } \\
\text { s), family 1 } \\
\text { gative, ER- } \\
\text { ed model); }\end{array}$ & $\begin{array}{l}\text { e serum bi } \\
\text { oker), age c } \\
\text { ry of breast } \\
\text { HER } 2+\text { su } \\
\text { CI- } 95 \% \text { cc }\end{array}$ & $\begin{array}{l}\text { kers; Mode } \\
\text { narche }(<12 \\
\text { er in first- o } \\
\text { e, luminal A } \\
\text { ence interva }\end{array}$ \\
\hline
\end{tabular}


In the higher level of the serum vitamin D concentration $(\geq 24.6 \mathrm{ng} / \mathrm{mL})$, the risk of breast cancer was lower by $67 \%$ (OR: $0.33 ; 95 \% \mathrm{Cl}: 0.11-0.97 ; p<0.05$; fully-adjusted model 3 ) and $72 \%$ (OR: 0.28 ; 95\% Cl: $0.10-0.78 ; p<0.05$; adjusted model 2) compared to the lower level (Table 9). In the higher level of the serum calcium concentration $(\geq 9.6 \mathrm{mg} / \mathrm{dL})$, the risk of breast cancer was lower by $62 \%$ (OR: 0.38; 95\% Cl: 0.18-0.79; $p<0.01$; unadjusted model 1 ) and 68\% (OR: 0.32; 95\% Cl: $0.11-0.91$; $p<0.05$; fully-adjusted model 3) compared to the lower level. In the higher level of the serum iron concentration $(\geq 103.0 \mu \mathrm{g} / \mathrm{dL}$ ), the risk of breast cancer was lower by $56 \%$ (OR: $0.44 ; 95 \% \mathrm{Cl}$ : 0.21-0.92; $p<0.05$; unadjusted model 1) compared to the lower level. This association disappeared after the adjustment. There were no significant associations of the serum level of folate, cobalamin, and magnesium considered separately with the risk of breast cancer (Table 9).

\section{Discussion}

To the authors' best knowledge, this is the first study describing the association between serum vitamin-mineral profile and breast cancer risk, which takes into account dietary patterns and vitamin/mineral supplement use in this area. The findings highlight the clear protective effect of the serum 'Iron-Calcium' profile as well as the protective effect of single biomarkers such as the higher-normal serum level of calcium and the slightly below the normal range of serum vitamin $\mathrm{D}$ level on the risk of breast cancer in postmenopausal women from north-eastern Poland. An inverse association of the serum 'Magnesium' profile and serum iron level with the risk of cancer was found, but it disappeared after adjustment. There was no significant association between serum 'Folate-Cobalamin-Vitamin D' profile or serum level of folate and cobalamin considered separately and cancer.

\subsection{Serum Vitamins and Minerals and Breast Cancer Risk}

The findings provide new insight into the importance of serum vitamins and minerals in breast cancer prevention. The 'Iron-Calcium' profile was positively loaded by the serum concentration of these minerals. A high adherence to the serum 'Iron-Calcium' profile was associated with an $88 \%$ decrease in breast cancer risk, and remained significant after adjustment for many confounders, including dietary patterns and supplement use. This strong association was obtained in a case-control study with a smaller strength of inference and needs to be confirmed in large prospective studies. Since the available studies have been focused mainly on single biomarkers in association with breast cancer, it is hard to compare the current results with others. In regard to the single serum minerals, it was found that a higher serum level of calcium $(\geq 9.6 \mathrm{mg} / \mathrm{dL})$ within the normal laboratory range (from 8.5 to $10.5 \mathrm{mg} / \mathrm{dL}$ ) [51] was associated with a $68 \%$ lower risk of breast cancer. These results are consistent with the findings from the Swedish Apolipoprotein Mortality Risk (AMORIS) prospective Study, which included 229,674 women and showed an inverse association between serum calcium and the risk of breast cancer, although this association was weaker [35]. A higher level of serum calcium $(\geq 9.8 \mathrm{mg} / \mathrm{dL})$ reduced the risk of breast cancer by $6 \%$ [35]. The protective role of calcium on breast tissue could possibly result from the influence on reduced breast density as an established risk factor of breast cancer [36]. This beneficial role of calcium was observed in the upper range of values considered normal, not above, because calcium homeostasis is carefully regulated by many mechanisms to maintain constant serum concentration [33]. In contrast, in the nested case-control Malmo Diet Cancer Study including 764 cases and 764 controls, serum calcium was positively associated with breast cancer, but only in premenopausal women [31]. However, in a prospective cohort study of 2338 women, Spraque et al. [37] showed no association between serum calcium and breast cancer risk was found, either overall or stratified by menopausal status.

Calcium metabolism is closely related to the vitamin D status [36]. Similar to the current results, in the French cohort study which obtained 1,908 women [18] was found that a $25(\mathrm{OH})$ vitamin D serum concentration was lower in cases compared to the controls ( 21.9 versus $29.5 \mathrm{ng} / \mathrm{mL}$, and 24.4 versus $25.1 \mathrm{ng} / \mathrm{mL}$, respectively), and this association was reported in other studies $[19,20]$. The serum level 
of $25(\mathrm{OH})$ vitamin $\mathrm{D}(\geq 24.6 \mathrm{ng} / \mathrm{mL})$ was slightly below the normal range ( $>30 \mathrm{ng} / \mathrm{mL})[52]$ and was associated with a lower risk of breast cancer by $67 \%$. This inverse association was also reported in most of the available studies [18-23,25-29,53]. The reduction in postmenopausal breast cancer risk ranged from $30 \%$ during the five year follow-up Sister Cohort Study of 3386 women [23] to 65\% in the pooled analysis of the randomized trial and prospective cohort study covering a total of 2304 women [22], when the serum 25(OH)D was more than $38.0 \mathrm{ng} / \mathrm{mL}$ and $40 \mathrm{ng} / \mathrm{mL}$, respectively. Such protective effect of vitamin $\mathrm{D}$ could be explained by regulation of cell proliferation and immune function, inhibition of metastasis and angiogenesis as well as induction of cell differentiation and apoptosis [54]. In addition, vitamin D inhibits the insulin-like growth factor I (IGF-I), which stimulates the growth of breast cancer cells [16]. However, other studies found no significant association between vitamin D levels and breast cancer risk [31,32]. Unexpectedly, the meta-analysis of three large European population-based cohort studies, conducted by Ordóñez-Mena et al. [30], showed increased breast cancer risk with higher $25(\mathrm{OH}) \mathrm{D}$ concentrations. This inconsistency among different studies may be related to differences in sample sizes, enrolled populations, study design, season of blood donation, and vitamin D measurements, the set of confounders taken into account and use different cut-off points according to serum levels of vitamin D were considered. Moreover, Shirazi et al. [27] in the nested case-control Malmo Diet and Cancer Study reported that women in the first and third tertile of the serum $25 \mathrm{OH}$ D3 level had a similar risk of breast cancer. Thus, these results suggested that both significant deficiencies and excessive levels of vitamin D are unfavorable.

Although high adherence to the serum 'Magnesium' profile decreased the risk of breast cancer, this association disappeared in the fully-adjusted model. There is a lack of epidemiological or clinical studies regarding the association between serum magnesium level and breast cancer risk. The molecular mechanism of the magnesium role in breast cancer etiology can be explained by a recent experimental study which suggested that the over-expression of oncogenic protein tyrosine phosphatase PRL-2 can promote oncogenesis by modulating intracellular magnesium levels through binding with the magnesium transporter [55]. The available data concerning the serum calcium to magnesium ratio in relation to breast cancer risk [38]. In the present study, the mean ratio of serum $\mathrm{Ca} / \mathrm{Mg}$ was 4.6 and was not significantly different depending on the cancer. In contrast, Sahmoun and Singh [38] showed that the serum $\mathrm{Ca} / \mathrm{Mg}$ ratio was higher in breast cancer cases than controls (4.9 versus 4.4), suggesting that a high serum $\mathrm{Ca} / \mathrm{Mg}$ ratio may be a risk factor for postmenopausal breast cancer. However, these results were obtained from the small preliminary data from medical charts review [38] and require confirmation in large studies. Nevertheless, an imbalance of the serum $\mathrm{Ca} / \mathrm{Mg}$ can lead to irregularities in mutually modulated signaling pathways and then to increase the risk of incorrect DNA repair, cell proliferation, and, consequently, to carcinogenesis [38].

Identification of the serum 'Iron-Calcium' profile supports the positive correlation between calcium and iron shown by Joo et al. [34] in a study with breast cancer patients. In the present study, the beneficial effect of the higher serum level of iron as a single biomarker was weak and disappeared after adjustment. However, a significant reduction in the risk of breast cancer was found with the elevated ferritin levels as one of the iron status markers in the prospective population-based EPIC-Heidelberg Study covering 627 breast cancer cases [40]. Conversely, in a Swedish cohort study [42] and in the prospective Busselton Health Study [43] involving 108,823 and 1795 women, respectively, elevated serum iron levels were associated with a greater risk of postmenopausal breast cancer. Contrary to the current results, Bae et al. [41] found a higher mean serum iron concentration and elevated serum iron level in breast cancer cases than in the controls, with 121 and 149 subjects, respectively. Excess iron may induce oxidative stress through the production of reactive oxygen species and lead to oxidative DNA damage and mammary carcinogenesis [41]. Furthermore, it was suggested that the higher incidence of breast cancer in postmenopausal women may result from two to three times higher serum Fe status than in premenopausal women due to cessation of menstrual bleeding [41].

Likewise, in some other studies, including the recent meta-analysis of four studies, no significant associations between the serum level of folate $[56,57]$ or vitamin B12 $[11,13]$ were found with the risk of 
breast cancer. However, Rossi et al. [12] in the prospective study conducted in the cohort of 1024 women, reported an inverse association between red blood cell folate levels and breast cancer risk mortality and $\mathrm{Wu}$ et al. [11] found a weak inverse association between serum vitamin B12 and breast cancer risk for the seven case-control studies that were separately considered. Several biological mechanisms for these inverse associations have been proposed. A deficiency in folate or vitamin B12 may result in an increase in genetic aberrations which have been implicated in neoplastic transformation [8]. Moreover, low B-group vitamins concentrations are associated with inflammation and higher oxidative stress which may lead to the carcinogenesis [8]. Interestingly, a positive association with the risk of breast cancer was observed for the high levels of vitamin B12 in women who abused alcohol [9] and for the high folate levels in women overall [13] as well as in women with BRCA1/2 mutations [15] and in women with estrogen receptor beta negative tumors [14]. The increased risk was attributed to excess supplementation. The aforementioned studies suggest both very low and very high folate levels could produce the potential harmful effects of folate due to abnormalities in DNA synthesis.

\subsection{Strengths and Limitations}

A major strength of this study is the novel approach in the breast cancer risk assessment by considering together blood concentrations of several vitamins and minerals as overall vitamin-mineral profiles. This is the first study to include the combined effects of serum levels of folate, vitamin B12, vitamin $\mathrm{D}$, calcium, iron, and magnesium on breast cancer risk. The strengths of the current study include the serum biomarker measurements, which are better reflected in the circulation nutrient status than other measures of exposure (e.g., dietary intake) and are not influenced by a recall bias [10]. Blood levels are the result of both dietary intake, supplementation, and endogenous synthesis, e.g. as an effect of sun exposure in the case of vitamin D [10]. Moreover, the measured serum 25-hydroxyvitamin $\mathrm{D}(25 \mathrm{OH} \mathrm{D})$ is currently considered the best marker of vitamin D status. Its half-life of about two to three weeks is 1000-fold longer than the half-life of 1,25(OH)2D [21]. Furthermore, all measurements, including the concentration of biomarkers, were made for the newly diagnosed breast cancer cases, prior to treatment or surgery, to avoid reverse causation, and minimize misclassification. Moreover, in order to exclude possible interference affecting vitamins and minerals levels, the blood sampling inclusion criteria were very restrictive and including fasting status, lack of diagnosed chronic diseases, and infections. Finally, in comprehensively evaluating the breast cancer risk, a wide range of potential confounders, including previously identified dietary patterns and respondents' statements about vitamin/mineral supplement use (or not) as additional nutrient sources were also taken into account. These strengthen the findings of the present study. Nevertheless, there are many other risk factors associated with breast cancer apart from diet and nutrients. The cancer etiology is complex and likely to be related to a combination and interactions of many factors, with included the immunology system condition and environmental pollution which are difficult to measure [5].

There are several study limitations. First, it was a relatively small sub-sample size. The cancer sub-sample size was limited by the number of breast cancer patients of the oncological surgery department in one hospital. Moreover, only newly diagnosed breast cancer cases, not benign or remission, qualified. However, the sample size (129) was greater than the minimum sample size (at least 42 of the controls and 42 of the cases) when calculated using the WHO sample size calculator considering $80 \%$ test power and 5\% significance level [58]. The second limitation is connected with the study design and sampling bias [59]. A non-random sample selection may reduce the strength and quality of evidence. The associations obtained from case-control studies compared to the prospective studies could be overstated due to recall or selection bias [59]. Nevertheless, after recruited cases and controls at the blood sampling, there was no need for further matching of these groups because of the lack differences in age and BMI between them. Thirdly, while assessing the cancer risk, the type and amount of nutrients taken with supplements, as well as the frequency of supplements use were not considered. In fact, an attempt was made to collect such data, but many respondents were unable to provide the composition of the supplements they took or name them, so a huge amount 
of data was missing. Therefore, respondents were only classified as either taking vitamin/mineral supplements within the last 12 months or not. Fourthly, a single blood draw for each subject was used for the measurement of biomarker levels and may not be representative in the long-term. However, in a recent cohort NHANES study that measured $25(\mathrm{OH}) \mathrm{D}$ at two times, three years apart, found a high inter-correlation between levels [21]. In regard to calcium, both short-time and long-time intra-individual variations in total serum calcium are low [37]. Thus, a single measurement of serum biomarkers is considered a valid marker of the status of selected nutrients.

\subsection{Clinical Impact and Future Directions}

The present findings indicate the need to include the monitoring of vitamin and mineral status, particularly calcium and vitamin $\mathrm{D}$, as endogenous markers in both conventional screening of breast cancer and in the treatment protocol. Further prospective studies with longitudinal measurements of serum biomarkers levels as well as randomized clinical trials are needed to establish cut-offs of the levels of vitamins and minerals which help to protect against breast cancer. In a further explanation of the role of nutrients in breast cancer etiology, genetic mutation carriers which have a genetic predisposition to develop highly aggressive cancers should be taken into account [44]. A better understanding of the impact of nutrients on the different stages and phenotypes of cancer development is essential for personalized treatment therapies directed towards nutrient-gene and nutrient-nutrient interactions and with prognostic significance for patient outcomes [44]. This will have important clinical implications.

\section{Conclusions}

In summary, the study revealed that a higher-normal serum level of both iron and calcium, considered together as the serum profile, as well as a higher-normal serum level of calcium, considered separately, and a slightly below the normal range of serum vitamin D level may protect against breast cancer among postmenopausal women, independent of dietary patterns or the use of vitamin/mineral supplements. In the prevention of breast cancer, special attention should be paid to maintaining adequate blood levels of vitamins and minerals and to preventing deficiencies. Thus, the regular monitoring of blood levels of their biomarkers should be included in a breast cancer reducing strategy.

Supplementary Materials: The following are available online at http://www.mdpi.com/2072-6643/11/9/2244/s1, Table S1: Cancer-control sample and its sub-sample characteristics (\%), Table S2: Cancer sample and its sub-sample characteristics (\%), Table S3: Control sample and its sub-sample characteristics (\%), Table S4: The cancer-control sub-sample characteristics by the serum vitamin-mineral profiles (\%), Table S5: Serum vitamins and mineral concentrations by the serum vitamin-mineral profiles $(\%)$ among postmenopausal women $(n=129)$, Table S6: Serum vitamins and minerals concentration by the serum vitamin-mineral profiles (\%) among postmenopausal women $(n=129)$. Figure S1: Histograms of serum $25(\mathrm{OH})$ vitamin D and calcium concentrations among control and cancer sub-samples.

Author Contributions: Conceptualization, B.K. and L.W.; data curation, B.K.; formal analysis, B.K.; funding acquisition, L.W. and M.D.; investigation, B.K.; methodology, B.K. and L.W.; project administration, B.K. and M.A.S.; resources, B.K. and M.B.; supervision, L.W.; visualization, B.K.; writing \& editing —original draft preparation, B.K.; writing-a critical review, L.W. All authors approved the final version of the manuscript to be published.

Funding: Project financially supported by Minister of Science and Higher Education in the range of the program entitled "Regional Initiative of Excellence" for the years 2019-2022, Project No. 010/RID/2018/19, amount of funding 12,000,000 PLN.

Acknowledgments: Thanks are expressed to the participants for their contributions to the study. Thanks are expressed to the K.S. from the Breast Prevention and Diagnosis Centre in Olsztyn for cooperation. Thanks are expressed to the laboratory staff, especially T.C. for performed laboratory analysis.

Conflicts of Interest: The authors declare no conflicts of interest. The funders had no role in the design of the study; in the collection, analyses, or interpretation of data; in the writing of the manuscript, or in the decision to publish the results. 


\section{References}

1. World Health Organization-Cancer Country Profiles. 2014. Available online: http://www.who.int/cancer/ country-profiles (accessed on 20 August 2017).

2. Ferlay, J.; Colombet, M.; Soerjomataram, I.; Mathers, C.; Parkin, D.M.; Piñeros, M.; Znaor, A.; Bray, F. Estimating the global cancer incidence and mortality in 2018: GLOBOCAN sources and methods. Int. J. Cancer 2019, 144, 1941-1953. [CrossRef] [PubMed]

3. Krajowy Rejestr Nowotworów, Centrum Onkologii-Instytut im. Marii Skłodowskiej-Curie (Polish National Cancer Registry, Oncology Centre. Institute of M. Sklodowska-Curie). Available online: http: //onkologia.org.pl/k/epidemiologia/ (accessed on 15 July 2019). (In Polish).

4. World Cancer Research Fund/American Institute for Cancer Research. Continuous Update Project Expert Report 2018. Diet, Nutrition, Physical Activity, and Breast Cancer; American Institute for Cancer Research: Washington, DC, USA, 2018.

5. Tao, Z.; Shi, A.; Lu, C.; Song, T.; Zhang, Z.; Zhao, J. Breast cancer: Epidemiology and etiology. Cell. Biochem. Biophys. 2015, 72, 333-338. [CrossRef] [PubMed]

6. Mahmoud, A.M.; Mohamed, M.A. Methyl donor micronutrients that modify DNA methylation and cancer outcome. Nutrients 2019, 11, 608. [CrossRef] [PubMed]

7. Norat, T.; Scoccianti, C.; Boutron-Ruault, M.C.; Anderson, A.; Berrino, F.; Cecchini, M.; Espina, C.; Key, T.; Leitzmann, M.; Powers, H.; et al. European Code against Cancer 4th Edition: Diet and cancer. Cancer Epidemiol. 2015, 39 (Supp1.1), S56-S66. [CrossRef] [PubMed]

8. Loda, M.; Mucci, L.A.; Mittelstadt, M.L.; Van Hemelrijck, M.; Cotter, M.B. Pathology and Epidemiology of Cancer; Springer: Berlin/Heidelberg, Germany, 2017; pp. 156-166.

9. Matejcic, M.; de Batlle, J.; Ricci, C.; Biessy, C.; Perrier, F.; Huybrechts, I.; Weiderpass, E.; Boutron-Ruault, M.C.; Cadeau, C.; His, M.; et al. Biomarkers of folate and vitamin B12 and breast cancer risk: Report from the EPIC cohort. Int. J. Cancer 2017, 140, 1246-1259. [CrossRef] [PubMed]

10. Millen, A.E.; Wactawski-Wende, J.; Pettinger, M.; Melamed, M.L.; Tylavsky, F.A.; Liu, S.; Robbins, J.; LaCroix, A.Z.; LeBoff, M.S.; Jackson, R.D. Predictors of serum 25-hydroxyvitamin D concentrations among postmenopausal women: The Women's Health Initiative Calcium plus Vitamin D Clinical Trial. Am. J. Clin. Nutr. 2010, 91, 1324-1335. [CrossRef] [PubMed]

11. Wu, W.; Kang, S.; Zhang, D. Association of vitamin B6, vitamin B12 and methionine with risk of breast cancer: A dose-response meta-analysis. Br. J. Cancer 2013, 109, 1926-1944. [CrossRef] [PubMed]

12. Rossi, E.; Hung, J.; Beilby, J.P.; Knuiman, M.W.; Divitini, M.L.; Bartholomew, H. Folate levels and cancer morbidity and mortality: Prospective cohort study from Busselton, Western Australia. Ann. Epidemiol. 2006, 16, 206-212. [CrossRef]

13. Essén, A.; Santaolalla, A.; Garmo, H.; Hammar, N.; Walldius, G.; Jungner, I.; Malmström, H.; Holmberg, L.; Van Hemelrijck, M. Baseline serum folate, vitamin B12 and the risk of prostate and breast cancer using data from the Swedish AMORIS cohort. Cancer Causes Control 2019, 30, 603-615. [CrossRef]

14. Ericson, U.; Borgquist, S.; Ivarsson, M.I.; Sonestedt, E.; Gullberg, B.; Carlson, J.; Olsson, H.; Jirstrom, K.; Wirfalt, E. Plasma folate concentrations are positively associated with risk of estrogen receptor beta negative breast cancer in a Swedish nested case-control study. J. Nutr. 2010, 140, 1661-1668. [CrossRef]

15. Kim, S.J.; Zuchniak, A.; Sohn, K.-J.; Lubinski, J.; Demsky, R.; Eisen, A.; Akbari, M.R.; Kim, Y.-I.; Narod, S.A.; Kotsopoulos, J. Plasma folate, vitamin B-6, and vitamin B-12 and breast cancer risk in BRCA1- and BRCA2-mutation carriers: A prospective study. Am. J. Clin. Nutr. 2016, 104, 671-677. [CrossRef] [PubMed]

16. O’Brien, K.M.; Sandler, D.P.; Xu, Z.; Karimi Kinyamu, H.; Taylor, J.A.; Weinberg, C.R. Vitamin D, DNA methylation, and breast cancer. Breast Cancer Res. 2018, 20, 70. [CrossRef] [PubMed]

17. Wilmanski, T.; Barnard, A.; Parikh, M.R.; Kirshner, J.; Buhman, K.; Burgess, J.; Teegarden, D. $1 \alpha, 25$-dihydroxyvitamin D inhibits the metastatic capability of MCF10CA1a and MDA-MB-231 cells in an in vitro model of breast to bone metastasis. Nutr. Cancer 2016, 68, 1202-1209. [CrossRef] [PubMed]

18. Engel, P.; Fagherazzi, G.; Boutten, A.; Dupré, T.; Mesrine, S.; Boutron-Ruault, M.C.; Clavel-Chapelon, F. Serum 25(OH) vitamin D and risk of breast cancer: A nested case-control study from the French E3N cohort. Cancer Epidemiol. Biomark. Prev. 2010, 19, 2341-2350. [CrossRef] [PubMed] 
19. Alipour, S.; Hadji, M.; Hosseini, L.; Omranipour, R.; Saberi, A.; Seifollahi, A.; Bayani, L.; Shirzad, N. Levels of serum 25-hydroxy-vitamin D in benign and malignant breast masses. Asian Pac. J. Cancer Prev. 2014, 15, 129-132. [CrossRef] [PubMed]

20. Shaukat, N.; Jaleel, F.; Moosa, F.A.; Qureshi, N.A. Association between vitamin D deficiency and breast cancer. Pak. J. Med. Sci. 2017, 33, 645-649. [CrossRef] [PubMed]

21. Estébanez, N.; Gómez-Acebo, I.; Palazuelos, C.; Llorca, J.; Dierssen-Sotos, T. Vitamin D exposure and risk of breast cancer: A meta-analysis. Sci. Rep. 2018, 13, 9039. [CrossRef]

22. McDonnell, S.L.; Baggerly, C.; French, C.B.; Baggerly, L.L.; Garland, C.F.; Gorham, E.D.; Lappe, J.M.; Heaney, R.P. Serum 25-hydroxyvitamin D concentrations $\geq 40 \mathrm{ng} / \mathrm{mL}$ are associated with $>65 \%$ lower cancer risk: Pooled analysis of randomized trial and prospective cohort study. PLoS ONE 2016, 11, e0152441. [CrossRef]

23. O'Brien, K.M.; Sandler, D.P.; Taylor, J.A.; Weinberg, C.R. Serum vitamin D and risk of breast cancer within five years. Environ. Health Persp. 2017. [CrossRef]

24. Kim, Y.; Je, Y. Vitamin D intake, blood $25(\mathrm{OH})$ D levels, and breast cancer risk or mortality: A meta-analysis. Br. J. Cancer 2014, 110, 2772. [CrossRef]

25. Mohr, S.B.; Gorham, E.D.; Alcaraz, J.E.; Kane, C.J.; Macera, C.A.; Parsons, J.K.; Wingard, D.L.; Garland, C.F. Serum 25-hydroxyvitamin D and prevention of breast cancer: Pooled analysis. Anticancer Res. 2011, 31, 2939-2948.

26. Bauer, S.R.; Hankinson, S.E.; Bertone-Johnson, E.R.; Ding, E.L. Plasma vitamin D levels, menopause, and risk of breast cancer: Dose-response meta-analysis of prospective studies. Medicine 2013, 92, 123-131. [CrossRef]

27. Shirazi, L.; Almquist, M.; Borgquist, S.; Malm, J.; Manjer, J. Serum vitamin D (25OHD3) levels and the risk of different subtypes of breast cancer: A nested case-control study. Breast 2016, 28. [CrossRef]

28. Tommie, J.L.; Pinney, S.M.; Nommsen-Rivers, L.A. Serum vitamin D status and breast cancer risk by receptor status: A systematic review. Nutr. Cancer 2018, 70, 804-820. [CrossRef]

29. Park, S.; Lee, D.H.; Jeon, J.Y.; Ryu, J.; Kim, S.; Kim, J.Y.; Park, H.S.; Kim, S.I.; Park, B.-W. Serum 25-hydroxyvitamin D deficiency and increased risk of breast cancer among Korean women: A case-control study. Breast Cancer Res. Treat. 2015, 152, 147-154. [CrossRef]

30. Ordonez-Mena, J.M.; Schottker, B.; Fedirko, V.; Jenab, M.; Olsen, A.; Halkjær, J.; Kampman, E.; de Groot, L.; Jansen, E.; Bueno-de-Mesquita, H.B.; et al. Pre-diagnostic vitamin D concentrations and cancer risks in older individuals: An analysis of cohorts participating in the CHANCES consortium. Eur. J. Epidemiol. 2016, 31, 311-323. [CrossRef]

31. Almquist, M.; Bondeson, A.-G.; Bondeson, L.; Malm, J.; Manjer, J. Serum levels of vitamin D, PTH and calcium and breast cancer risk-A prospective nested case-control study. Int. J. Cancer 2010, 127, 2159-2168. [CrossRef]

32. Skaaby, T.; Husemoen, L.L.; Thuesen, B.H.; Pisinger, C.; Jorgensen, T.; Roswall, N.; Larsen, S.C.; Linneberg, A. Prospective population-based study of the association between serum 25-hydroxyvitamin-D levels and the incidence of specific types of cancer. Cancer Epidemiol. Biomark. Prev. 2014, 23, 1220-1229. [CrossRef]

33. Cross, B.M.; Breitwieser, G.E.; Reinhardt, T.A.; Rao, R. Cellular calcium dynamics in lactation and breast cancer: From physiology to pathology. Am. J. Physiol. Cell Physiol. 2014, 306, C515-C526. [CrossRef]

34. Joo, N.-S.; Kim, S.-M.; Jung, Y.-S.; Kim, K.-M. Hair iron and other minerals' level in breast cancer patients. Biol. Trace Elem. Res. 2009, 129, 28-35. [CrossRef]

35. Wulaningsih, W.; Sagoo, H.K.; Hamza, M.; Melvin, J.; Holmberg, L.; Garmo, H.; Malmström, H.; Lambe, M.; Hammar, N.; Walldius, G.; et al. Serum calcium and the risk of breast cancer: Findings from the Swedish AMORIS Study and a meta-analysis of prospective studies. Int. J. Mol. Sci. 2016, 17, 1487. [CrossRef]

36. Hack, C.C.; Stoll, M.J.; Jud, S.M.; Heusinger, K.; Adler, W.; Haeberle, L.; Ganslandt, T.; Heindl, F.; Schulz-Wendtland, R.; Cavallaro, A.; et al. Correlation of mammographic density and serum calcium levels in patients with primary breast cancer. Cancer Med. 2017, 6, 1473-1481. [CrossRef]

37. Sprague, B.L.; Skinner, H.G.; Trentham-Dietz, A.; Lee, K.E.; Klein, B.E.K.; Klein, R. Serum calcium and breast cancer risk in a prospective cohort study. Ann. Epidemiol. 2010, 20, 82-85. [CrossRef]

38. Sahmoun, A.E.; Singh, B.B. Does a higher ratio of serum calcium to magnesium increase the risk for postmenopausal breast cancer? Med. Hypotheses 2010, 75, 315-318. [CrossRef]

39. Jian, J.; Yang, Q.; Dai, J.; Eckard, J.; Axelrod, D.; Smith, J.; Huang, X. Effects of iron deficiency and iron overload on angiogenesis and oxidative stress-a potential dual role for iron in breast cancer. Free Radic. Biol. Med. 2011, 50, 841-847. [CrossRef] 
40. Quintana, P.D.A.; Sookthai, D.; Graf, M.E.; Schübel, R.; Johnson, T.; Katzke, V.A.; Kaaks, R.; Kühn, T. Iron status in relation to cancer risk and mortality: Findings from a population-based prospective study. Int. J. Cancer 2018, 143, 561-569. [CrossRef]

41. Bae, Y.-J.; Yeon, J.-Y.; Sung, C.-J.; Kim, H.-S.; Sung, M.-K. Dietary intake and serum levels of iron in relation to oxidative stress in breast cancer patients. J. Clin. Biochem. Nutr. 2009, 45, 355-360. [CrossRef]

42. Gaur, A.; Collins, H.; Wulaningsih, W.; Holmberg, L.; Garmo, H.; Hammar, N.; Walldius, G.; Jungner, I.; Van Hemelrijck, M. Iron metabolism and risk of cancer in the Swedish AMORIS study. Cancer Causes Control 2013, 24, 1393-1402. [CrossRef]

43. Chua, A.C.G.; Knuiman, M.W.; Trinder, D.; Divitini, M.L.; Olynyk, J.K. Higher concentrations of serum iron and transferrin saturation but not serum ferritin are associated with cancer outcomes. Am. J. Clin. Nutr. 2016, 104, 736-742. [CrossRef]

44. Combet, E.; Gray, S.R. Nutrient-nutrient interactions: Competition, bioavailability, mechanism and function in health and diseases. Proc. Nutr. Soc. 2019, 78, 1-3. [CrossRef]

45. Krusinska, B.; Wadolowska, L.; Slowinska, M.A.; Biernacki, M.; Drozdowski, M.; Chadzynski, T. Associations of dietary patterns and metabolic-hormone profiles with breast cancer risk: A case-control study. Nutrients 2018, 10, 2013. [CrossRef]

46. Armitage, P.; Berry, G.; Matthews, J.N.S. Statistical Methods in Medical Research, 4th ed.; Blackwell Science: Oxford, UK, 2001.

47. Lidia Wadolowska Website. Available online: http://www.uwm.edu.pl/edu/lidiawadolowska/ (accessed on 20 July 2018).

48. Niedzwiedzka, E.; Wadolowska, L.; Kowalkowska, J. Reproducibility of a non-quantitative Food Frequency Questionnaire (62-item FFQ-6) and PCA-driven dietary pattern identification in 13-21-year-old females. Nutrients 2019, 11, 2183. [CrossRef]

49. Wadolowska, L.; Krusinska, B. Manual for developing nutritional data from the KomPAN questionnaire. In Dietary Habits and Nutrition Beliefs Questionnaire and Manual for Developing Nutritional Data; Gawecki, J., Ed.; The Committee of Human Nutrition, Polish Academy of Sciences: Warsaw, Poland, 2014; pp. 34-51.

50. World Cancer Research Fund/American Institute for Cancer Research. Food, Nutrition, Physical Activity, and the Prevention of Cancer: A Global Perspective; American Institute for Cancer Research: Washington, DC, USA, 2007.

51. Walker, H.K.; Hall, W.D.; Hurst, J.W. Clinical Methods: History, Physical, and Laboratory Examinations, 3rd ed.; Butterworths: Boston, MA, USA, 1990.

52. Holick, M.F. Vitamin D status: Measurement, interpretation and clinical application. Ann. Epidemiol. 2009, 19, 73-78. [CrossRef]

53. Kim, Y.; Franke, A.A.; Shvetsov, Y.B.; Wilkens, L.R.; Cooney, R.V.; Lurie, G.; Maskarinec, G.; Hernandez, B.Y.; Le Marchand, L.; Henderson, B.E.; et al. Plasma 25-hydroxyvitamin D3 is associated with decreased risk of postmenopausal breast cancer in whites: A nested case-control study in the multiethnic cohort study. BMC Cancer 2014, 14, 29. [CrossRef]

54. Atoum, M.; Alzoughool, F. Vitamin D and breast cancer: Latest evidence and future steps. Breast Cancer 2017, 11, 1-8. [CrossRef]

55. Hardy, S.; Uetani, N.; Wong, N.; Kostantin, E.; Labbé, D.; Bégin, L.R.; Mes-Masson, A.; Miranda-Saavedra, D.; Tremblay, M.L. The protein tyrosine phosphatase PRL-2 interacts with the magnesium transporter CNNM3 to promote oncogenesis. Oncogene 2015, 34, 986-995. [CrossRef]

56. Lin, J.; Lee, I.M.; Cook, N.R.; Selhub, J.; Manson, J.; Buring, J.E.; Zhang, S.M. Plasma folate, vitamin B-6, vitamin B-12, and risk of breast cancer in women. Am. J. Clin. Nutr. 2008, 87, 734-743. [CrossRef]

57. Kotsopoulos, J.; Kim, Y.-I.; Narod, S. Folate and breast cancer: What about high-risk women? Cancer Cause Control 2012, 23, 1405-1420. [CrossRef]

58. World Health Organization. STEPS Sample Size Calculator and Sampling Spreadsheet. Available online: https://www.who.int/ncds/surveillance/steps/resources/sampling/en/ (accessed on 20 July 2019).

59. Song, J.W.; Chung, K.C. Observational Studies: Cohort and Case-Control Studies. Plast. Reconstr. Surg. 2010, 6, 2234-2242. [CrossRef]

(C) 2019 by the authors. Licensee MDPI, Basel, Switzerland. This article is an open access article distributed under the terms and conditions of the Creative Commons Attribution (CC BY) license (http://creativecommons.org/licenses/by/4.0/). 